\title{
Analysis of Cacao and Coconut Intercrop Farming on Production Centers in Central Sulawesi Province
}

\author{
Rosida P. Adam ${ }^{a^{*}}$, Johanis Panggeso ${ }^{b}$, Suardi ${ }^{\mathrm{c}}$ \\ ${ }^{\mathrm{a}, \mathrm{b}, \mathrm{c}}$ Department of development Study, Faculty of Economy, University Tadulako, Palu, Central Sulawesi \\ *Email: rosida_adam@yahoo.co.id
}

\begin{abstract}
The title of the research is Analysis of Cocoa and Coconut Intercrop Farming on Production Centers in Central Sulawesi Province. The purpose of this study is to identify and analyze the benefits of Intercrop Cocoa and Coconut for farmers. Central Sulawesi government has divided four centers of cocoa and purposive sampling researches, focused on two (2) superior centers, i.e Sentra I, includes: Donggal, and Sigi. Meanwhile, Sentra II includes: Moutong Parigi District, Poso District, and Tojo Una-Una District. Results of research descriptively explained that Cocoa and Coconut Intercrop Farming indicates good intercrop, measured from the distance between coconut cocoa, i.e approximately $3.5 \mathrm{~m}$ in average. However, some overlaps are still found in some locations. There are still other crops found among Cocoa and Coconut Intercrop, thus the growth of Cocoa and Coconut is not maximum. Another benefit of the cultivation of cocoa under coconut trees is it can improve the efficiency in the use of land and sunlight. In addition, Coconut can indirectly help to control Helopeltis palm plant biologically as black ants (Dolichoderus thoracicus) prefer to nest in palm tree, which will destroy Helopeltis.
\end{abstract}

Keywords: Intercrop Cocoa, Coconut Farming, Revenue Analysis.

\section{Introduction}

Intercrop (Tumpang Sari) system aims to optimize farmer's revenue or to anticipate the risk of price and production uncertainty. Previous research by [1] stated the difference of farm's revenue in various intercrop systems on cacao farming in Geulumpang sub-district. Central Sulawesi is highly potential towards the system development of cacao-based agribusiness, either plantation or cacao processing industry. However, according to [2] the farmer is facing various issues, such as: low production due to various diseases and pests, the failure of Gernas program, and the same price of fermented and unfermented cacao seed product in collecting traders. Entomophatogenic fungi, i.e. B. bassiana, Aspergillus sp., Gliocephalis sp., Fusarium sp., and Penicillium sp., was generated from kadaver pupa PBK in cacao farming ecosystem in Central Sulawesi [3]. Fusarium sp., Rhizopus sp., and Gliocladium sp. were also found in 2009, and Trichoderma sp. [4]. Previous studies only found $B$. bassiana as entomophatogenic fungus in PBK pest. However, the role of Penicillium is higher than $B$. bassiana and Aspergillus sp. [3]. Furthermore, [5] reported that natural agent treatment of Trichoderma sp. and Gliocladium sp. combination is able to reduce the intensity of Rhizoctonia solani disease in corn plantation until $90 \%$. The ulitization of natural agent, such as: virus, mushroom or fungi, bacteria or ascomycetes. Trichoderma spp. is potential as natural agent of pathogenic fungi [6]. Trichoderma spp., through mycoparasitism process, antibiosis, and competition, is able to resist the growth of pathogen development [7]. According to the land aspect, the root deployment of mature-coconut plant is reaching the maximum height of 2 meters around the plants and depth of 0-60 centimeters. In 2 meter radius, the root deployment is ranging from 76 t0 $85 \%$. Beyond that space limit, the land can be utilized for other variety of plants, as long as it can tolerate the canopy [8].

\section{Research Method}

According to research objective, this research is conducted by using descriptive, qualitative, quantitave, and action methods. Descriptive method is used to describe specific illustration on the studied objects. Meanwhile, action research is a process done by people or group who are expecting the change in certain situations to examine the process that is estimated to yield the changes. Further, the process yields the conclusion that can be considered and conducted [9]; [10]. Analysis method used in this research is descriptive analysis, which is a method to describe specific illustration on the studied variables or indicators, both quantitatively and qualitatively.

\section{Results And Discussion}

Research result of Coconut and Cacao Intercrop Farming, based on the frequency distribution of the spread planting distance in research location, illustrated in Table 1 as follows: 
Table 1. Planting Distance of Cacao - Coconut Intercrop

\begin{tabular}{|c|c|c|c|c|c|c|c|c|c|c|c|c|c|c|c|}
\hline \multirow{4}{*}{ No } & \multirow{4}{*}{$\begin{array}{l}\text { Planting } \\
\text { Distance } \\
\text { Kakao- } \\
\text { Kelapa }\end{array}$} & \multicolumn{14}{|c|}{ DISTRICT/CITY } \\
\hline & & \multicolumn{6}{|c|}{ PARIMO } & \multirow{2}{*}{\multicolumn{2}{|c|}{$\begin{array}{l}\text { TOUNA } \\
\text { Village Saluaba }\end{array}$}} & \multirow{2}{*}{\multicolumn{2}{|c|}{$\begin{array}{l}\text { DONGGALA } \\
\text { Village } \\
\text { Lumbumamara }\end{array}$}} & \multirow{2}{*}{\multicolumn{2}{|c|}{$\begin{array}{l}\text { SIGI } \\
\text { Village } \\
\text { Makmur }\end{array}$}} & \multirow{2}{*}{\multicolumn{2}{|c|}{$\begin{array}{l}\text { POSO } \\
\text { Village Maju Lea }\end{array}$}} \\
\hline & & \multicolumn{2}{|c|}{$\begin{array}{l}\text { Village } \\
\text { Toribulu }\end{array}$} & \multicolumn{2}{|c|}{$\begin{array}{l}\text { Village } \\
\text { Lambunu }\end{array}$} & \multicolumn{2}{|c|}{ Village Indah } & & & & & & & & \\
\hline & & $\sum$ & $\%$ & $\sum$ & $\%$ & $\sum$ & $\%$ & $\sum$ & $\%$ & $\sum$ & $\%$ & $\sum$ & $\%$ & $\sum$ & $\%$ \\
\hline 1 & $<1 \mathrm{M}$ & - & - & - & - & - & - & - & - & 2 & 11.8 & - & - & - & - \\
\hline 2 & $1-2 \mathrm{M}$ & - & - & 1 & 10.0 & 3 & 33.3 & 1 & 7.7 & 7 & 41.2 & 5 & 26.3 & - & - \\
\hline 3 & $3-4 \mathrm{M}$ & 11 & 100.0 & 9 & 90.0 & 6 & 66.7 & 12 & 92.3 & 8 & 47.1 & 14 & 73.7 & 8 & 100.0 \\
\hline Tot & & 11 & 100.0 & 10 & 100.0 & 9 & 100.0 & 13 & 100.0 & 17 & 100 & 19 & 100.0 & 8 & 100.0 \\
\hline
\end{tabular}

Table 1 illustrates the majority of planting distance between cacao and coconut is $3-4$ meters in average. However, in Desa Lumbumamara, there are plants in $1-2$ meter distance. It can be described that the concentration of coconut root is in radius 2 meters from the trunk.
Hence, the minimum distance of cacao and coconut trunk is 3 meters. Although, lateral root of cacao grows aside until the edge of canopy, the most distribution of root is only reaching 90-120 centimeters from the trunk. Thus, the 3 meter distance of cacao and coconut is quite reasonable

Table 2. Surface area of cacao - coconut intercrop

\begin{tabular}{|c|c|c|c|c|c|c|c|c|c|c|c|c|c|c|c|}
\hline \multirow{4}{*}{ No } & \multirow{4}{*}{$\begin{array}{c}\text { Surface Area } \\
\text { Kakao (ha) }\end{array}$} & \multicolumn{14}{|c|}{ DISTRICT/CITY } \\
\hline & & \multicolumn{6}{|c|}{ PARIMO } & \multirow{2}{*}{\multicolumn{2}{|c|}{$\begin{array}{c}\text { TOUNA } \\
\text { Village Saluaba }\end{array}$}} & \multirow{2}{*}{\multicolumn{2}{|c|}{$\begin{array}{c}\text { DONGGALA } \\
\text { Village } \\
\text { Lumbumamara }\end{array}$}} & \multirow{2}{*}{\multicolumn{2}{|c|}{$\begin{array}{c}\text { SIGI } \\
\text { Village } \\
\text { Makmur }\end{array}$}} & \multirow{2}{*}{\multicolumn{2}{|c|}{$\begin{array}{c}\text { POSO } \\
\text { Village Maju } \\
\text { Lea } \\
\end{array}$}} \\
\hline & & \multicolumn{2}{|c|}{$\begin{array}{c}\text { Village } \\
\text { Toribulu }\end{array}$} & \multicolumn{2}{|c|}{$\begin{array}{c}\text { Village } \\
\text { Lambunu }\end{array}$} & \multicolumn{2}{|c|}{ Village Indah } & & & & & & & & \\
\hline & & $\sum$ & $\%$ & $\sum$ & $\%$ & $\sum$ & $\%$ & $\sum$ & $\%$ & $\sum$ & $\%$ & $\sum$ & $\%$ & $\sum$ & $\%$ \\
\hline 1 & $\leq 1$ & 5 & 45.5 & 2 & 20.0 & 4 & 44.4 & 8 & 61.5 & 13 & 76.5 & 13 & 68.4 & 3 & 37.5 \\
\hline 2 & $>1-2$ & 4 & 36.4 & 2 & 20.0 & 2 & 22.2 & 1 & 7.7 & 1 & 5.9 & 5 & 26.3 & 3 & 37.5 \\
\hline 3 & $>2-3$ & 1 & 9.1 & 4 & 40.0 & - & - & 2 & 15.4 & 1 & 5.9 & 1 & 5.3 & 1 & 12.5 \\
\hline 4 & $>3-4$ & 1 & 9.1 & 1 & 10.0 & 3 & 33.3 & 2 & 15.4 & 2 & 11.8 & - & - & 1 & 12.5 \\
\hline 5 & $>4 \mathrm{ha}$ & - & - & 1 & 10.0 & - & - & - & - & - & - & - & - & - & - \\
\hline & Total & 11 & 100 & 10 & 100.0 & 9 & 100 & 13 & 100.0 & 17 & 100 & 19 & 100.0 & 8 & 100.0 \\
\hline
\end{tabular}

Table 2 above illustrates the average samples (farmers) own 1 -2 ha intercrop area of cacao - coconut. However, the number of farmers is relatively small. Commonly, the farmers firstly cultivate coconut with $7-10$ meters distance. To optimize the land, the farmers cultivate cacao in between the spaces.

Table 3. Cacao production

\begin{tabular}{|c|c|c|c|c|c|c|c|c|c|c|c|c|c|c|c|}
\hline \multirow{4}{*}{ No } & \multirow{4}{*}{$\begin{array}{c}\text { Cacao } \\
\text { Production } \\
\text { (Kg/Harvest } \\
\text { Time) }\end{array}$} & \multicolumn{14}{|c|}{ DISTRICT/CITY } \\
\hline & & \multicolumn{6}{|c|}{ PARIMO } & \multirow{2}{*}{\multicolumn{2}{|c|}{$\begin{array}{l}\text { TOUNA } \\
\text { Village } \\
\text { Saluaba } \\
\end{array}$}} & \multirow{2}{*}{\multicolumn{2}{|c|}{$\begin{array}{c}\text { DONGGALA } \\
\text { Village } \\
\text { Lumbumamara }\end{array}$}} & \multirow{2}{*}{\multicolumn{2}{|c|}{$\begin{array}{c}\text { SIGI } \\
\text { Village } \\
\text { Makmur } \\
\end{array}$}} & \multirow{2}{*}{\multicolumn{2}{|c|}{$\begin{array}{c}\text { POSO } \\
\text { Village Maju } \\
\text { Lea } \\
\end{array}$}} \\
\hline & & \multicolumn{2}{|c|}{$\begin{array}{c}\text { Village } \\
\text { Toribulu }\end{array}$} & \multicolumn{2}{|c|}{$\begin{array}{c}\text { Village } \\
\text { Lambunu }\end{array}$} & \multicolumn{2}{|c|}{$\begin{array}{c}\text { Village Suli } \\
\text { Indah }\end{array}$} & & & & & & & & \\
\hline & & $\sum$ & $\%$ & $\sum$ & $\%$ & $\Sigma$ & $\%$ & $\sum$ & $\%$ & $\sum$ & $\%$ & $\sum$ & $\%$ & $\sum$ & $\%$ \\
\hline 1 & $\leq 20 \mathrm{Kg}$ & - & - & - & - & - & - & 1 & 7.7 & 3 & 17.6 & 12 & 63.2 & - & - \\
\hline 2 & $>20-40 \mathrm{Kg}$ & - & - & - & - & - & - & 2 & 15.4 & 2 & 11.8 & 1 & 5.3 & 1 & 12.5 \\
\hline 3 & $>40-60 \mathrm{Kg}$ & 3 & 27.3 & - & - & 2 & 22.2 & 1 & 7.7 & 4 & 23.5 & 4 & 21.1 & 2 & 25.0 \\
\hline 4 & $>60-80 \mathrm{Kg}$ & 2 & 18.2 & 1 & 10.0 & - & - & 2 & 15.4 & 3 & 17.6 & 2 & 10.5 & - & - \\
\hline 5 & $>80 \mathrm{Kg}$ & 6 & 54.5 & 9 & 90.0 & 7 & 77.8 & 7 & 53.8 & 5 & 29.4 & - & - & 5 & 62.5 \\
\hline & Total & 11 & 100 & 10 & 100 & 9 & 100.0 & 13 & 100 & 17 & 100 & 19 & 100 & 8 & 100 \\
\hline
\end{tabular}

Table 3 above illustrates the production achieved by farmers, i.e $40-80 \mathrm{~kg} /$ harvest time $/ 2$ weeks in average for $1-2$ ha land. Low production is due to pests and cancer diseases of cacao, which are attacting the plants. Therefore, the farmers are desperate on cacao maintenance and development.

Table 4. Coconut production

\begin{tabular}{|c|c|c|c|c|c|c|c|c|c|c|c|c|c|c|c|}
\hline \multirow{4}{*}{ No } & \multirow{4}{*}{ Coconut Production } & \multicolumn{14}{|c|}{ DISTRICT/CITY } \\
\hline & & \multicolumn{6}{|c|}{ PARIMO } & \multirow{2}{*}{\multicolumn{2}{|c|}{$\begin{array}{c}\text { TOUNA } \\
\text { Village } \\
\text { Saluaba }\end{array}$}} & \multirow{2}{*}{\multicolumn{2}{|c|}{$\begin{array}{c}\text { DONGGALA } \\
\text { Village } \\
\text { Lumbumamara }\end{array}$}} & \multirow{2}{*}{\multicolumn{2}{|c|}{$\begin{array}{c}\text { SIGI } \\
\text { Village } \\
\text { Makmur }\end{array}$}} & \multirow{2}{*}{\multicolumn{2}{|c|}{$\begin{array}{c}\text { POSO } \\
\begin{array}{l}\text { Village Maju } \\
\text { Lea }\end{array}\end{array}$}} \\
\hline & & \multicolumn{2}{|c|}{$\begin{array}{l}\text { Village } \\
\text { Toribulu }\end{array}$} & \multicolumn{2}{|c|}{$\begin{array}{c}\text { Village } \\
\text { Lambunu }\end{array}$} & \multicolumn{2}{|c|}{$\begin{array}{l}\text { Village Suli } \\
\text { Indah }\end{array}$} & & & & & & & & \\
\hline & & $\sum$ & $\%$ & $\sum$ & $\%$ & $\sum$ & $\%$ & $\sum$ & $\%$ & $\sum$ & $\%$ & $\sum$ & $\%$ & $\sum$ & $\%$ \\
\hline 1 & $<200$ seeds & 3 & 27.3 & - & - & - & - & - & - & - & - & 6 & 31.6 & 8 & 100.0 \\
\hline 2 & $>200-300$ seeds & 1 & 9.1 & 2 & 20.0 & - & - & 6 & 46.2 & 11 & 64.7 & 3 & 15.8 & - & - \\
\hline 3 & $>300-600$ seeds & - & - & 1 & 10.0 & - & - & 2 & 15.4 & 4 & 23.5 & 3 & 15.8 & - & - \\
\hline 4 & $>600-900$ seeds & - & - & 1 & 10.0 & - & - & - & - & - & - & - & - & - & - \\
\hline 5 & $>900-1.200$ seeds & 1 & 9.1 & 2 & 20.0 & 3 & 33.3 & 2 & 15.4 & 2 & 11.8 & - & - & - & - \\
\hline 6 & $>1.200$ seeds & 6 & 54.5 & 4 & 40.0 & 6 & 66.7 & 3 & 23.1 & - & - & 7 & 36.8 & - & - \\
\hline & Total & 11 & 100.0 & 10 & 100.0 & 9 & 100.0 & 13 & 100 & 17 & 100.0 & 19 & 100.0 & 8 & 100.0 \\
\hline
\end{tabular}


Table 4 illustrates coconut production achieved by farmers, i.e $300-6.000$ seeds/harvest time $/ 3$ months. It signifies that low production is due to the average age of coconut trees, i.e $40-100$ years old.

Table 5 Working capital of cacao-coconut intercrop farming

\begin{tabular}{|c|c|c|c|c|c|c|c|c|c|c|c|c|c|c|c|}
\hline \multirow{4}{*}{ No } & \multirow{4}{*}{$\begin{array}{l}\text { Working Capital } \\
\text { (Thousands) }\end{array}$} & \multicolumn{14}{|c|}{ DISTRICT/CITY } \\
\hline & & \multicolumn{6}{|c|}{ PARIMO } & \multirow{2}{*}{\multicolumn{2}{|c|}{$\begin{array}{l}\text { TOUNA } \\
\text { Village } \\
\text { Saluaba }\end{array}$}} & \multirow{2}{*}{\multicolumn{2}{|c|}{$\begin{array}{c}\text { DONGGALA } \\
\text { Village } \\
\text { Lumbumamara }\end{array}$}} & \multirow{2}{*}{\multicolumn{2}{|c|}{$\begin{array}{c}\text { SIGI } \\
\text { Village } \\
\text { Makmur }\end{array}$}} & \multirow{2}{*}{\multicolumn{2}{|c|}{$\begin{array}{c}\text { POSO } \\
\begin{array}{l}\text { Village Maju } \\
\text { Lea }\end{array}\end{array}$}} \\
\hline & & \multicolumn{2}{|c|}{$\begin{array}{c}\text { Village } \\
\text { Toribulu }\end{array}$} & \multicolumn{2}{|c|}{$\begin{array}{l}\text { Village } \\
\text { Lambunu }\end{array}$} & \multicolumn{2}{|c|}{$\begin{array}{c}\text { Village } \\
\text { Suli Indah }\end{array}$} & & & & & & & & \\
\hline & & $\sum$ & $\%$ & $\sum$ & $\%$ & $\sum$ & $\%$ & $\sum$ & $\%$ & $\sum$ & $\%$ & $\sum$ & $\%$ & $\sum$ & $\%$ \\
\hline 1 & $\leq \operatorname{Rp} 300$ & 3 & 27.3 & 4 & 40.0 & - & - & 2 & 15.4 & 8 & 47.1 & 1 & 5.3 & 1 & 12.5 \\
\hline 2 & $>\operatorname{Rp} 300-\operatorname{Rp} 600$ & 5 & 45.5 & 5 & 50.0 & - & - & 9 & 69.2 & 4 & 23.5 & 8 & 42.1 & 3 & 37.5 \\
\hline 3 & $>\operatorname{Rp} 600-\operatorname{Rp} 900$ & - & - & 1 & 10.0 & - & - & - & - & 2 & 11.8 & - & - & 1 & 12.5 \\
\hline 4 & $>\operatorname{Rp} 900-\operatorname{Rp} 1.2 \mathrm{jt}$ & 2 & 18.2 & - & - & 5 & 55.6 & 1 & 7.7 & 1 & 5.9 & 2 & 10.5 & 3 & 37.5 \\
\hline 5 & $>\mathrm{Rp} 1.2 \mathrm{jt}$ & 1 & 9.1 & - & - & 4 & 44.4 & 1 & 7.7 & 2 & 11.8 & 8 & 42.1 & - & - \\
\hline & Total & 11 & 100 & 10 & 100.0 & 9 & 100.0 & 13 & 100.0 & 17 & 100 & 19 & 100.0 & 8 & 100.0 \\
\hline
\end{tabular}

Table 5 illustrates the average working capital paid by the farmers for maintenance, medical fee, fertilization, harvest time, and post-harvest time, i.e $300-600$ thousands/ha/year. It indicates that farmers posses minimum working capital. Cacao - coconut plants require high production cost, particularly the cost of processing coconut into copra. Meanwhile, the cost of $O P T$ control and cacao cancer disease is the priority cost for cacao farming. Rosida, et all (2015) has conducted research on controlling trunk cancer and cacao fruit. Research found that the utilization of resources in surrounding plantations to produce trichoderma plus and bokhasi fertilizer is effective and efficient for the farmers.

Productivity level of Coconut and Cacao Intercrop produced by farmers in research samples, illustrated in the following table:

Table 6. Productivity of coconut cacao intercrop (Ton/Ha/Year)

\begin{tabular}{|c|l|l|l|}
\hline NO & DISTRICT & COCONUT & CACAO \\
\hline 1 & TOJO UNA-UNA & 1,20 & 0,54 \\
\hline 2 & POSO & 2,95 & 0,73 \\
\hline 3 & PARIMO & 1,03 & 0,52 \\
\hline 4 & DONGGALA & 1,01 & 0,74 \\
\hline 5 & SIGI & 0,45 & 0,67 \\
\hline
\end{tabular}

Table 6 illustrates productivity of cacao-coconut intercrop that signifies the highest level of cacao commodity is obtained by sampled farmers in Donggala District. Meanwhile, the lowest level of productivity is obtained by PArigi Moutong District. Furthermore, the highest level of coconut commodity is obtained by farmers in Poso District, while the lowest level is obtained by farmers in Sigi District. Some factors are due to pest diseases that have attacked since post-Gernas, 2009. This situation indicates that both intercrop plants are mutually beneficial for Cacao-Coconut Intercrop Farming income.

Table 7. The Average Income of Cacao - Coconut Intercrop Farmers/year/ha

\begin{tabular}{|c|l|l|l|c|}
\hline No & Income Source & Revenue (Rp) & Production Cost (Rp) & Income (Rp) \\
\hline 1 & Cacao Farming & 16.640 .000 & 4.992 .000 & 11.648 .000 \\
\hline 2 & Coconut Farming & 13.280 .000 & 7.968 .000 & 5.312 .000 \\
\hline & Total & 29.920 .000 & 12.960 .000 & 16.960 .000 \\
\hline
\end{tabular}

Table 7 above illustrates the income of cacao - coconut intercrop farmers, i.e $\mathrm{Rp} 16.960 .000$ per year/ha. The income is obtained from cacao farming, i.e $\mathrm{Rp} \mathrm{11.648.000}$ $(68,7 \%)$. Meanwhile, the income from copra is $\mathrm{Rp}$ $5.312 .000(31,3 \%)$ per year/ha. The problems faced by intercrop farmers mainly are the high cost in processing coconut into copra. The average cost of processing is $60 \%$ of revenue. Therefore, the farmers are inclined to trade the whole coconut seeds to factories, with the price of $\mathrm{Rp}$ $1.000-1.200 /$ seed. This price is considered more profitable and reliable to obtain trading results because coconut distribution sytem is done by factories, by collecting coconuts from the farmers.

Furthermore, the cost of cacao maintenance and processing is $30 \%$ of the farmer's revenue. However, that cost is used to purchase pesticide and fertilizer to cope with quite critical trunk or fruit cancer (Ventricular Septal Defect/VSD). However, some research locations have applied natural treatment by using the technology, which has been accepted since the research conducted by Rosida, 
et al (2015). This technology is effective and efficicent by using local materials and in two weeks trunk and fruit cancer diseases can be overcome.

\section{Conclusion and Recommendation \\ 4.1 Conclusion}

According to research results, it can be concluded:

1. Farmer's social status in Coconut - Cacao Intercrop Farming signifies the average age of farmers, ranging from 35 to 55 years old and the average level of education is SMP (Junior High School).

2. The characteristic of plant pattern of cacao coconut intercrop signifies good intercrop, measured by planting distance of coconut - cacao in average $3,5 \mathrm{~m}$. However, some overlaps are still found in some locations. There are still other crops found among Cacao and Coconut Intercrop. Therefore, the growth and yields of Cacao and Coconut are not optimum.

3. The characteristic of the plant pattern of cacao and coconut intercrop indicates good intercrop, measured by planting distance of coconut - cacao in average $3,5 \mathrm{~m}$.

\subsection{Recommendation}

1. Some overlaps are still found in Coconut - Cacao Intercrop Farming. The farmers are suggested to destroy the other crops, hence the planting distance between Cacao - Coconut is fulfill the standard to increase the optimum result.

2. The farmer's stewardship method in Intercrop System can be conducted by rejuvenating the unproductive coconut plants. The coconut intercrop is potential both economically and noneconomically.

3. Should Government launch sustainable supervision programs to cope with the problems of cacao, by providing trainings to produce bokhasi fertilizer and trichoderma that are generated from potential local materials in surrounding plantations.

\section{References}

[1] Sofyan, Susanti, E., and Dahlia. 2015. Analisis Usahatani Kakao Rakyat Pada Berbagai Pola Tanam Tumpang Sari Di Kecamatan Geulumpang Tiga Kabupaten Pidie. Banda Aceh: Faculty of Agriculture, Syiah University. Agrisep Vol (16) No. 1.

[2] Adam, R., Darman, S., and Panggeso, J. 2015. Implementasikan model strategi pengembangan agribisnis untuk peningkatan produksi, pengendalian penyakit kanker stadium awal pada tanaman kakao dan peningkatan nilai tambah produk. Semarang: Proceding, Perhepi

[3] Nurariaty, A. 2006. Identifikasi Cendawan Entomopatogen dan Perannya sebagai Agen Hayati Pupa Penggerek Buah kakao (Conopomorpha cramerella snellen) (Lepidoptera:Gracillariidae) di Pertanaman Kakao. Buletin Penelitian Seri Hayati 9(2): 94-180.

[4] Nurariaty, A. 2010. Isolasi dan Pertumbuhan Beberapa Cendawan Entomopatogen pada pupa Penggerek Buah Kakao, Conopomorpha cramerella (Snellen). Makassar: Faculty of Agriculture, Hasanuddin University.

[5] Mulyati, S. 2013. Kebutuhan Pengembangan Usaha Kakao dengan Pendekatan Rantai Nilai. Kerjasama antara Ford Foundation dengan Komite Pemantauan Pelaksanaan Otonomi Daerah. Jakarta: Komite Pemantauan Pelaksanaan Otonomi Daerah

[6] Tindaon, H. 2008. Pengaruh Jamur Antagonis Trichoderma harzianum dan Pupuk Organik Untuk Mengendalikan Patogen Tular Tanah Sclerotium roflsii Sacc. Pada Tanaman Kedelai (Glycine max L.) di Rumah Kasa. Retrieved from http://repository.usu.ac.id.pdf (10 August 2010)

[7] Rifai, M., Mujim, S., and Aeny, T.N. 1996. Pengaruh Lama Investasi Trichoderma viride Terhadap Intensitas Serangan Pythium sp. Pada Kedelai. Jurnal VII 8: 20-25

[8] Syakir, M. 2010. Budidaya dan Pasca Panen Kakao. Bogor: Puslitbang Perkebunan Bogor

[9] Uma, S. 2004. Research Methods for Business, A AkillBuilding Approach. Thirt Edition, John Wiley \& Sons, Inc., America.

[10] Sugiono.1999. Metode Penelitian Bisnis. Bandung: CV. Alfabeta. 